Volume 17, Issue 1, (2022) 193-204

www.cjes.eu

\title{
Macroeconomics and active methodologies in higher education: A possible pairing and a possible binomial
}

\author{
Asier Arcos-Alonso ${ }^{a^{*},}$ Profesor Laboral Interino, Universidad del País Vasco UPV/EHU, Spain \\ https://orcid.org/0000-0001-8737-5531 \\ María Garcia-Alvarez ${ }^{\text {b }}$, Profesor Laboral Interino, Universidad del País Vasco UPV/EHU, Spain \\ https://orcid.org/0000-0003-1822-3264
}

Amaia Garcia Azpuru c, Universidad del País Vasco UPV/EHU, Spain http://orcid.org/0000$\underline{0002-9053-4393}$

\section{Suggested Citation:}

Arcos-Alonso, A., Garcia-Alvarez, M \& Azpuru, A. G., (2022). Macroeconomics and active methodologies in higher education: A possible pairing and a possible binomial. Cypriot Journal of Educational Science. 17(1), 193-204. https://doi.org/10.18844/cjes.v17i1.6695

Received from October 30, 2021; revised from November 11, 2021; accepted from January 10, 2022. (C)2022 Birlesik Dunya Yenilik Arastirma ve Yayincilik Merkezi. All rights reserved.

\begin{abstract}
This article presents an experience of teaching innovation based on the application of active methodologies in economics and business education at the University of the Basque Country (UPV/EHU). The proposal builds on a competency teaching approach, whose objectives were to verify the effectiveness of these methodologies in the area of economics in order to reconnect the university with its social environment and enhance the competency and student-learning values. During the 2019-2020 academic year, a multidisciplinary process based on the ProblemBased Learning methodology was developed in the Introduction to Economics II: Principles of Macroeconomics course. Various teaching techniques were applied to encourage participation, autonomous student work, group work, as well as elements of social responsibility and values education. The results of the process collected quantitatively and qualitatively show improvements in the acquisition of knowledge by students and greater appropriation levels linked to greater motivation. However, reluctance and misgivings about the process also arose, which would require further work in class and a leading role by students. Greater planning, time and coordination requirements were also limiting factors for the teaching staff; however, the relevance of applying the methodology sequentially is suggested.
\end{abstract}

Keywords: Active methodology, higher education, social and ethical responsibility, active learning, skills, economy.

\footnotetext{
${ }^{*}$ ADDRESS OF CORRESPONDENCE: Asier Arcos-Alonso, University of the Basque Country UPV/EHU, Vitoria-Gasteiz, Spain.

Email address: asier.arcos@ehu.eus
} 


\section{Introduction}

We live in a world where more and more voices are raised and claiming that we are immersed in a globalising process. It is a context where there is an intersection of crises at a structural, systemic, multiple and related level (Del Rio \& Celorio, 2018; Rauber, 2011). It is an increasingly complex environment where changes affect more levels and occur more rapidly over time. It has repercussions, therefore, on the different dimensions in which human beings develop economic, social, cultural, emotional etc. - and the university environment is no stranger to this (Arcos-Alonso et al., 2018).

The Spanish university currently suffers from various problems or dysfunction. however; This article aims to address 'two problems' in particular: a) the gradual disconnection between the university environment and the society that surrounds it, and b) the need for active methodologies that serve as both a tool to solve this disconnection and are adaptable to teaching based on the acquisition of competencies.

The gradual distancing that is taking place between the university and society generates a state of disconnection between the interests of society and the role of the universities, which on occasions becomes mere trainers of professionals for the system. This is undoubtedly one of their main objectives, and in the case of Spain, it is partly due to the professionalising nature that university education has traditionally had. Even so, it should not be forgotten that this must go hand in hand with its task of generating a critical spirit and transmitting human values, so that they coincide as closely as possible with the interests of society and the environment in which they operate (Arcos-Alonso, Elías-Ortega \& Arcos-Alonso, 2020). In short, the school - or university - as an institution that trains new generations has the obligation to keep in touch with the reality that surrounds it and to propose alternatives to prepare its students for the future (Cárdenas \& Rivera, 2004).

Faced with the social and economic challenges of the 21st century, an attempt is being made at the European university level to respond to them. Thus, the European Higher Education Area was created, which is currently the convergence plan, with the aim of promoting the mobility of citizens and the development of the continent, which crystallised in the Bologna Declaration of 1999. This will generate important changes in Spanish universities (Jimenez, Lagos \& Jareno, 2013). One of the most important will be the change to an educational model based on a competency-based approach, which becomes a fundamental element in the construction of the 'learning throughout life' system, an essential element for achieving greater competitiveness in Europe, improving social cohesion, equal opportunities and quality of life (Hernandez, Renart \& Manzano, 2009). It implies a profound change in the teaching-learning paradigm, as the leading role of teachers shifts to a state in which students play a fundamental role in their own learning. Thus, autonomous and self-regulated learning will be encouraged, with the teacher assuming a guiding role. In this way, the traditional university culture based on the master class will change to one based on interaction and, to a certain extent, horizontality. A profound change of roles between student and teacher. It is at this point where the question arises: Is it necessary to think about the application of teaching methodologies more in line with this new paradigm? What are they? How to apply them? What facilitating role can Information and Communication Technologies (ICT) play?

It seems pertinent to think about the need to change teaching proposals and create new keys in university teaching (Lopez, Benedito \& Leon, 2016). Teaching combines in the same classroom an eminently practical nature, a multidisciplinary approach that helps students to understand and be part of their training process, using innovative methodologies that encourage participation and bring them closer to the social reality of their environment. The use of active methodologies thus acquires great importance (PBL, cases, projects etc.), as it favours the development of a culture of collaboration that overcomes disciplinary visions, diversifies 
assessments and deepens the learning achieved (Arcos-Alonso \& Alonso-Olea, 2020). It also helps to improve students' methodological competences, which will be of great interest for their personal and professional future (Garay-Argandona et al., 2021). Furthermore, studies indicate that active learning increases the success rate of students by more than 5\% (Freeman et al., 2014), which supports the adoption of these methodologies.

It should also be noted that this experience is in line with the UPV/EHU's own teaching model: the IKD Model - Cooperative and Dynamic Learning - which proposes cooperation between the agents of the educational community, projects and initiatives around the teaching-learning processes, in a climate of mutual trust ${ }^{\dagger}$.

We are facing the challenge of responding to this new context through the application of active teaching methodologies. Problem Based Learning (PBL) has proven to be one of the most highly valued by students as it enables the direct acquisition of experience, learning of skills and understanding of concepts (Ortiz, 2019; Hernandez et al., 2009). On the other hand, the Bachelor's Degree in Business Administration and Management (DBAM) marks as transversal competences autonomous learning, teamwork, capacity for analysis and synthesis, social and ethical responsibility and, in particular, decision-making and problem-solving, among others. All of them can be conveniently worked on through active methodologies, particularly through PBL from a multidisciplinary approach, given that previous studies show that the acquisition of transversal competences is not limited to problem-solving skills, but that other related competences are also greatly reinforced, especially those linked to their cooperative approach (Jimenez et al., 2013).

PBL emerged in the 1950s in the United States and was soon applied at McMaster University medical school in Canada. The methodology was then adopted in other medical schools in the Netherlands, Australia and New Mexico and implemented in other disciplines such as business and education (Penalosa, 2019; Boud \& Feletti, 2013).

In PBL, the teacher poses a problem-situation and from there the students become the protagonists of their own learning through a self-directed process tutored by the teacher (Hmelo-Silver, 2004; Wood, 2003). It is not about solving problems per se, but once appropriate problems have been posed to increase students' knowledge and understanding, they will use trigger questions from the problem case or scenario to reach a final resolution.

The process is defined and the variations that exist follow a similar series of steps. PBL may, or may not, focus on problem-solving with a given solution, and additionally enables the development of other desirable skills and attributes. These include knowledge acquisition, communication, teamwork, problem-solving, independent responsibility for learning, information sharing and respect for others. Thus, PBL is a teaching method that combines knowledge acquisition with the development of generic skills and attitudes (Wood, 2003). It encourages a deeper approach to learning, promotes versatility, explores methods and improves knowledge retention, research and application skills. Teachers may also find it satisfying (Forsythe, 2002), as it helps their own motivation. Moreover, the potential of methodologies that involve the combined responsibility of students and teachers in the generation of knowledge that favours a professional development that is permeable and sensitive to the changes occurring in the social and labour world (Arcos-Alonso \& Arcos Alonso, 2021).

On this research, the application and analysis of PBL was carried out in a first-year core subject, as a result of a training process promoted by the UPV/EHU's Educational Counselling Service

\footnotetext{
${ }^{\dagger}$ For further information consult ehu.eus/es/web/sae-helaz/ikd
} 
Arcos-Alonso, A., Garcia-Alvarez, M \& Azpuru, A. G., (2022). Macroeconomics and active methodologies in higher education: A possible pairing and a possible binomial. Cypriot Journal of Educational Science. 17(1), 193-204 https://doi.org/10.18844/cjes.v17i1.6695

(SAE-HELAZ), in the 'Workshop on the Application of Active Methodologies', where the practical application of various active methodologies, including PBL, was proposed.

Several authors have investigated the application of the methodology in subjects related to the teaching of economics or business management and administration (Kinsella, 2008; Mergendoller et al., 2006; Forsythe, 2002), or in particular, with the teaching of macroeconomics and related subjects (Jimenez et al., 2013; Klein, 2008; Maxwell et al., 2004). It highlights the fact that since the teaching constructs are different from traditional ones, a great deal of planning, time and resources are required to adapt them to the classroom. As a result, it is possible, and sometimes desirable, to apply it sequentially in the subject over several consecutive years.

Additionally, it is important to note the use of new ICTs in university teaching as an agent of change in educational practices (Sarkar, 2012). They help to improve their quality and effectiveness by supporting collaborative learning processes that require interaction between teachers and students (Salinas, 2004).

\section{Material and methods}

The teaching innovation process was applied within the framework of the subject 'Introduction to Economics II: Principles of Macroeconomics', which is taught in the first year of the Degree in Business Administration and Management at the Faculty of Economics and Business Administration (DBAM) of the UPV/EHU, Vitoria-Gasteiz section.

It is a case study, which consists of an in-depth analysis of a theoretical sample that does not seek generalization but rather the creation of knowledge that can be used in analogous or similar contexts (Stake, 1998) and that can probably be replicated or extended (Eisenhardt, 1989). On the other hand, reliability and trustworthiness are guaranteed by an accurate design of the case study, and the subsequent triangulation of quantitative, qualitative and bibliographic data (Carazo, 2006).

In this particular case, two different evaluation systems were offered: Continuous Assessment System (CA) and Final Assessment System (FE) (Table 1).

Table 1. Evaluation systems

\begin{tabular}{lcc}
\hline & CA & FA \\
\hline Tasks & $30 \%$ & \\
Final Test & $70 \%$ & $100 \%$ \\
Final Marks Subject & $100 \%$ & $100 \%$ \\
\hline
\end{tabular}

\subsection{Participants and description of participants}

The participant group was made up of first-year students -mostly people between 17-18 yearsold- in the first four-month period of the course, $39.5 \%$ of whom were women and $60.5 \%$ men. In total there were ninety-four participants, distributed in two groups: G1 and G2. Table 2 shows their overall composition and its breakdown according to sexes and evaluation systems requested. 
Table 2. Description of the participants

\begin{tabular}{|c|c|c|c|c|c|c|}
\hline \multirow[b]{2}{*}{ G1 } & \multicolumn{2}{|c|}{ Students enrolled } & \multicolumn{2}{|r|}{ Students presented } & \multirow{2}{*}{$\begin{array}{c}\begin{array}{c}\text { Women } \\
\text { (presented to CA } \\
\text { and FA) }\end{array} \\
16\end{array}$} & \multirow{2}{*}{$\begin{array}{c}\text { Men (presented } \\
\text { to CA and FA) }\end{array}$} \\
\hline & 50 & $\mathrm{~F}: 18$ [36\%] & 45 & CA: 40 [88.9\%] & & \\
\hline & & M: 32 [64\%] & & FA: 5 [11.1\%] & 1 & 4 \\
\hline \multirow[t]{2}{*}{ G2 } & 44 & $\mathrm{~F}: 18$ [41\%] & 42 & CA: 38 [90.5\%] & 15 & 23 \\
\hline & & M: 26 [59\%] & & FA: 4 [9.5\%] & 2 & 2 \\
\hline \multirow[t]{2}{*}{ Total } & 94 & F: 36 [38.3\%] & 87 & CA: 78 [89.7\%] & 31 & 47 \\
\hline & & M: 58 [61.7\%] & & FA: 9 [10.3\%] & 3 & 6 \\
\hline
\end{tabular}

G: group F: female M: male CA: continuous assessment FA: final assessment (single evaluable test)

In general, the majority of students (89.7\%) opted for the continuous assessment system ${ }^{1}$, regardless of the group analysed or the sex of the students ( $91.2 \%$ of women and $88.7 \%$ of men).

Based on these premises, the course was designed in such a way that $75 \%$ of the continuous assessment marks was assigned to tasks or activities based on active methodologies (T1, T3 and T4) and the remaining 25\% to other types of methodology (Table 3). The relative weight assigned to these active methodology tasks on the total final marks (Table 1) was not due to their inadequacy for the learning process of students in economics and business studies, but due to the novelty of their application in this area of knowledge. As the aforementioned authors pointed out, the innovative nature of these methodologies makes it necessary for their implementation or putting into practice to be progressive, with a relatively low weight with respect to the final assessment of the subject, at least in the first stages of testing, as in this case.

\subsection{Methodological process}

The research used as information production techniques the exploitation of the quantitative results of tasks and tests developed, and the narrative technique of the teacher's diary, a qualitative methodology, where notes were collected on the opinion of students and teachers about the methodology applied. Both methodologies were used simultaneously throughout the term.

Quantitative methodology:

The subject was planned with measurable and achievable objectives in each task, but which at the same time responded to the global objectives focused on the acquisition of competences by the students with a view to their future insertion in the labour market (Miguez \& Gil, 2012). The 'competence objectives at subject level were as follows:

1. Encourage autonomous learning and cooperative work, the management and resolution of concerns, interests and possible conflicts in groups.

2. To promote the capacity for reflection, analysis and synthesis at group and individual level in relation to real and current problems and situations related to macroeconomics.

3. Design and implement new practical teaching activities that promote interdisciplinarity.

4. Transversalise elements of social responsibility and ethics linked to the teaching of economics in the content and learning process.

5. To work on students' decision-making skills when faced with real-life problems. 
Arcos-Alonso, A., Garcia-Alvarez, M \& Azpuru, A. G., (2022). Macroeconomics and active methodologies in higher education: A possible pairing and a possible binomial. Cypriot Journal of Educational Science. 17(1), 193-204

https://doi.org/10.18844/cjes.v17i1.6695

The teacher designed a system of continuous and formative assessment so that she could observe whether the students were acquiring the new concepts proposed, allowing her to ask them open questions as a trigger (Butler et al., 2001) on which to work actively. Students were accompanied throughout the process, with significant time and effort allocated by the teacher and constant feedback provided (Brown \& Long, 2006). The continuous assessment thus proposed involved the completion of six tasks. All tasks were evaluated and graded. Table 3 shows the tasks carried out in the teaching innovation process. The UPV/EHU's Moodle platform for virtual support for the teaching- eGela-was used, as well as various applications contained therein to make the tasks feasible and facilitate student-teacher interaction.

Table 3. Description of tasks carried out

\begin{tabular}{llcccc}
\hline \multicolumn{1}{c}{ TASK } & $\begin{array}{c}\text { Presential [P] / } \\
\text { Non-presential } \\
\text { [NP] }\end{array}$ & $\begin{array}{c}\text { Group [G] / } \\
\text { Non-group } \\
\text { [NG] }\end{array}$ & $\begin{array}{c}\text { Methodology/Active } \\
\text { Techniques }\end{array}$ & $\begin{array}{c}\text { Weight } \\
\text { Grades/Total } \\
\text { Tasks (\%) }\end{array}$ \\
\hline T1 & Glossary of terms & P & G & Yes & 10 \\
T2 & Comment article & P & G & No & 5 \\
T3 & Poster & P & G & Yes & 25 \\
T4 & PBL problem & P & G & Yes & 40 \\
T5 & Exercises & P & NG & No & 5 \\
T6 & Press pack & NP & G & No & 15 \\
& & & & & $100 \%$ \\
\hline
\end{tabular}

Three of the tasks (T1, T3 and T4) were based on active methodologies, representing $75 \%$ of the total number of tasks developed, and 2.25 points out of 10 with respect to the final marks for the subject. These tasks were group tasks performed during class time and, therefore, they could be perfectly tutored by the teacher who was able to give them the necessary feedback to complete their learning and achieve the objectives previously set.

These practices favoured in-depth learning, collaborative learning, the capacity for reflection and the acquisition of certain transversal competences, such as autonomous learning, teamwork, capacity for analysis and synthesis, social and ethical responsibility and decisionmaking and problem-solving. The tasks were worked on in 2-hour sessions, with each of the two subject groups, and in a classroom where tables and chairs are movable, which allows group work to develop more adequately. The whole learning process was also supported through the use of ICTs by students and teachers, thus improving the interaction, quality and effectiveness of the learning process.

The task 1 (T1) consisted of the elaboration of a glossary of macroeconomic terms and was carried out using the participatory technique ' $1+2+4$ '. This activity was designed as an introductory task whose 'objectives' were to identify the basic macroeconomic concepts that appear in journalistic texts, to understand and define these concepts and to understand that the subject is related to events in the economic reality.

A text was handed out with three excerpts from current news reports on different economic topics: GDP, unemployment and public deficit. In the first phase, students were asked to read the text individually and identify the relevant macroeconomic terms. In the second phase, students in pairs had to collate the identified concepts, agree on a list of them and make a first definition of terms without external help. In the third phase, the students, working in groups of four, had to complete a single list of concepts and define them, for which they could make use of their mobile devices (phones, laptops, iPad etc.). Finally, there was a sharing session, where 
each group explained the concepts worked on and the rest of the students contributed comments and improvements. A student, appointed as secretary, wrote down the terms and definitions, completing a glossary of terms that was posted on the eGela platform so that all students had easy access to it.

The T3 task was a micro-PBL project using the poster technique. With the aim of working on the transversal competence of social and ethical responsibility, students were asked to carry out a small research project on a social issue using other types of indicators linked to the concept of development (Human Development Index, Ecological Footprint, etc.) and to present it in poster format. The 'objectives' of this micro-project were to reflect on social and ethical responsibility, to identify and understand alternative indicators for measuring social well-being, and to synthesise and disseminate the information in a clear and concise way.

In order to carry out this task, and bearing in mind that these are first-year students who are not yet familiar with the different forms of research dissemination, in a previous class the teacher showed them academic posters and explained the criteria they had to meet. On the day of the practical, students were asked to form groups and discuss a social issue of interest to them. Each group had to carry out a small research project on the selected topic and then present the research in poster format. The posters were displayed in the classroom and a spokesperson for each group explained the main ideas of their research to the rest. Students participated by asking questions and providing comments.

The T4 task was an actual PBL. This practice was carried out when the vast majority of the syllabus had been covered, so that the students could understand the subject in its entirety, internalise it and see its applicability to the current socio-economic reality. The 'objectives' of this PBL were to understand, analyse and relate macroeconomic concepts, use data search tools and interpret them, show writing skills through a written presentation and be able to solve and make decisions regarding the problem posed.

The students were presented with a problem to solve, in order for them to develop an active role. They were given a triggering problem to solve: 'You have been appointed as economic advisors of the Autonomous Community of the Basque Country (ACBC). You have to make an analysis of the current economic situation of the ACBC and, as advisors to the government, propose an appropriate fiscal policy taking this situation into account'. Initially, they had to identify the basic indicators of the economic situation of the ACBC and looked up the current value and trend of these indicators in a database. Then, using their ability to interpret these data and understand the economic situation of the $A C B C$, they proposed the most appropriate fiscal policy based on their interpretation. Finally, each group wrote a coherent report justifying their response and the cooperative process of adopting the most appropriate solution.

\section{Qualitative methodology:}

The narrative technique of teacher's diary facilitated the collection of notes about the activities developed and their assessment, and of the students' answers to questions posed about the whole PBL learning process (positive aspects, difficulties and problems encountered, proposals for improvement).

This collection made it possible to monitor the process and compare the students' skills and knowledge, and to detect elements for improvement at an early stage.

\subsection{Analysis and results}

The analysis of the results is twofold. On the one hand, a quantitative analysis will be carried out; and on the other, a qualitative analysis will be carried out based on the collection of the pupils' voices in relation to the methodology used, which in turn has served as a source of contrast for the whole process. 
Arcos-Alonso, A., Garcia-Alvarez, M \& Azpuru, A. G., (2022). Macroeconomics and active methodologies in higher education: A possible pairing and a possible binomial. Cypriot Journal of Educational Science. 17(1), 193-204

https://doi.org/10.18844/cjes.v17i1.6695

\subsection{Quantitative analysis}

Analysing the academic results obtained in this subject, it was observed that the percentage of passes was considerably higher among students who took the continuous assessment than among those who took the final assessment. More specifically, of the total number of students who sat the ordinary exams for the subject, those who opted for continuous assessment passed $41 \%$, while those who were assessed with a single final exam had a $22.2 \%$ pass rate. Therefore, it can be interpreted that the fact of following continuous training in which active methodologies are used improves the students' performance and training, favouring their subsequent passing rate.

It is also worth mentioning that $85 \%$ of the students who took the continuous assessment passed, with no significant differences between the sexes, with both showing similar results. However, the 20-point bias between the two class groups (G1: $75 \%$ and $\mathrm{G} 2: 95 \%$ ) could be due to their idiosyncrasies. (See Table 4 for the number of people who passed the programmed tasks and the continuous assessment.)

Table 4. Passes in the continuous assessment system by tasks

Approved continuous task-based assessment

\begin{tabular}{|c|c|c|c|c|c|c|c|c|c|c|c|c|c|c|}
\hline & & \multicolumn{2}{|l|}{ T1 } & \multicolumn{2}{|l|}{ T2 } & \multicolumn{2}{|l|}{ T3 } & \multicolumn{2}{|l|}{ T4 } & \multicolumn{2}{|l|}{ T5 } & T6 & \multicolumn{2}{|c|}{$\begin{array}{c}\text { Continuous } \\
\text { assessment } \\
\text { approved }\end{array}$} \\
\hline G1 & & & & & & & & & & & & & 30 & \\
\hline \multirow[t]{2}{*}{ [40] } & 36 & $\mathrm{~F}: 14$ & 39 & $\mathrm{~F}: 16$ & 40 & $\mathrm{~F}: 16$ & 40 & $\mathrm{~F}: 16$ & 14 & $\mathrm{~F}: 3$ & 17 & $\mathrm{~F}: 11$ & [75\%] & F: 12 \\
\hline & & M: 22 & & $M: 23$ & & $M: 24$ & & $M: 24$ & & $M: 11$ & & M: 6 & & M: 18 \\
\hline \multirow{3}{*}{$\begin{array}{c}\text { G2 } \\
{[38]}\end{array}$} & & & & & & & & & & & & & 36 & \\
\hline & 37 & $\mathrm{~F}: 15$ & 37 & $\mathrm{~F}: 15$ & 36 & $\mathrm{~F}: 15$ & 34 & $\mathrm{~F}: 13$ & 12 & F: 5 & 35 & F: 15 & [95\%] & $F: 15$ \\
\hline & & $M: 22$ & & $M: 22$ & & $M: 21$ & & $M: 21$ & & M: 7 & & $M: 20$ & & M: 21 \\
\hline \multirow{3}{*}{$\begin{array}{c}\text { Total } \\
\text { [78] }\end{array}$} & & & & & & & & & & & & & 66 & \\
\hline & 73 & F: 29 & 76 & $\mathrm{~F}: 31$ & 76 & $\mathrm{~F}: 31$ & 74 & F: 29 & 26 & F: 8 & 52 & F: 26 & [85\%] & F: 27 \\
\hline & & M: 44 & & M: 45 & & $M: 45$ & & M: 45 & & $M: 18$ & & M: 26 & & M: 39 \\
\hline
\end{tabular}

The data point to greater student success in those active methodology tasks (T1, T3 and T4) that were guided by the teacher, interpreting this as an achievement in motivating, stimulating, accompanying learning and enabling students to achieve the objectives set.

On the other hand, it was observed that the good results obtained in the continuous assessment did not correspond in number or percentage with the final marks. An $85 \%$ pass rate in CA only ensured a $41 \%$ pass rate in the final marks for the subject, less than half. This was interpreted not only as the result of a student profile that had just made the academic leap from baccalaureate or vocational training to degree studies (university), which may cause some academic dispersion among students, who must adapt to new work dynamics, to social circles and environments different from their usual ones, and to decision-making and responsibilities with which they may not be familiar but also as a possible mismatch between the methodologies used in the assessment. While the CA had $75 \%$ of the tasks based on active and innovative methodologies, the final test was still based on the traditional test-exam methodology, with the latter having a higher weight on the final marks (Table 1 ) and the CA mark not being taken into account if a 3.2 was not reached in the final exam (Table 5).

Table 5. Comparison of passes according to the assessment systems 
Arcos-Alonso, A., Garcia-Alvarez, M \& Azpuru, A. G., (2022). Macroeconomics and active methodologies in higher education: A possible pairing and a possible binomial. Cypriot Journal of Educational Science. 17(1), 193-204 https://doi.org/10.18844/cjes.v17i1.6695

\begin{tabular}{lcccc}
\hline & $\begin{array}{c}\text { Approved continuous } \\
\text { assessment system }\end{array}$ & $\begin{array}{c}\text { Approved final assessment } \\
\text { system }\end{array}$ \\
\hline G1 [45] & 13 & F: 6 & 1 & F: 1 \\
M: 7 & M: 0 \\
\hline G2 [42] & 19 & M: 8 & 1 & F: 1 \\
\hline Total [87] & 32 & F: 14 & 2 & M: 0 \\
& & M: 18 & & F: 2 \\
\end{tabular}

In summary, the dynamics of teaching innovation were relevant for this subject, but not the methodological imbalance and disconnection in the different assessment items leading to the final mark, nor the weight or relevance of each one of them. However, he did highlight the good results obtained among the students in active methodology tasks, not only in terms of qualification but, above all, in terms of student motivation and ability to achieve the objectives and competences set out in the subject and the degree to which it is attached. Moreover, the incorporation of ICTs did not present any inconvenience for the students. This data was also contrasted and corroborated through the field notes collected by the teacher from the pupils, which will be detailed below.

\subsection{Qualitative analysis}

The qualitative analysis was carried out on the basis of the students' voices collected in the teacher's diary as the tasks were being completed, extracts of which are shown below.

There was notable acceptance of the change in teaching methodology. There was greater motivation among the students, particularly in relation to participatory and cooperative work. 'This working in groups... is already seen in other subjects as well, and the truth is that it's good'. The fact of having to work from educational approaches where the students assumed a leading role was positively valued: 'Now we can make more contributions in class, and on top of that we can talk about social issues and link them to macroeconomics. It puts us in the real world' or 'Now I understand better the news I see on Instagram'. The application of participatory techniques was liked and amused the students, although sometimes they were put off by it and misgivings arose about 'wasting time' with 'these things'. 'When are you going to give it to us?' or 'Will we have time to see everything?'.

On the other hand, as the term progressed, fatigue was noticeable. Not only due to this process, but also to the fact that other subjects meant a significant concentration of homework. 'You all send us assignments and all we do is work! You could coordinate yourselves better, because the continuous evaluations keep us busy all the time'.

The same fatigue was observed in the teaching staff. The very process of designing and planning the subject on the one hand, and the constant work of dynamization, the continuous marking process, the requirements of formative assessment and feedback on the other, meant a greater teaching effort.

These 'voices' served as a contrast to the quantitative results obtained. If the quantitative results suggested that the application of active methodologies had been beneficial in terms of learning and grading, the qualitative results supported this evidence.

\section{Discussion}

This is constructivist learning in which both, the teacher and the student, play a proactive role, with the learner taking the leading role. 
The implementation of this active methodology, more innovative, in conjunction with traditional methodologies showed the existence of a methodological gap between both. The results in the continuous assessment were optimal, but the final marks in the subject were not so good, as a consequence of the final individual test. In this sense, there are experiences that seem to indicate the relevance of applying active methodologies (not only PBL) for the acquisition of competences by students (Arcos-Alonso \& Alonso-Olea, 2020; Arcos-Alonso et al., 2021; Prieto et al., 2021; among others). Although the methodological suitability surely needs to be fine-tuned.

In this way, it was confirmed that continuous assessment, based on active methodologies and formative techniques, including PBL, was motivating for the students who obtained extraordinary results in this part in general terms, achieving, in addition, the competences set in the objectives of the tasks and of the subject itself. In other words, PBL works in terms of activating prior knowledge in the small group setting and provides opportunities for the co-elaboration of meaningful learning. Furthermore, PBL activities - and active methodologies in general - facilitate the understanding of new information related to the problem situation at hand and enhance long-term recall. This has already been analysed by Schmidt et al. (2011) who asserted that there is evidence that problems arouse situational interest that drives learning. (...) Small group work protects against dropping out of school and encourages students to study regularly'.

All this also showed the need to adapt the final exam in terms of both methodology and relative weight in the final marks for the subject. Specifically, a reflection on the relevance of planning the subject in such a way as to offer greater cohesion between the methodologies used in teaching and thus maintain an evaluative balance in terms of student marks. This would favour greater linearity between formative and evaluative assessment, avoiding possible gaps between them that would make students lose the perspective of how to approach the subject.

As with other similar experiences in the classroom (Arcos-Alonso et al., 2021), there have been limitations concerning the management of teachers and their training in active methodologies. It was understood that there could be certain limitations when applying these teaching innovation methodologies if the SAE-HELAZ did not provide sufficient monitoring of the teaching staff in this type of activities, if there was a lack of experience or training of the teacher or if the available spaces and material resources were inadequate for developing these methodologies.

\section{Conclusion}

The UPV/EHU's commitment to teaching innovation is clear, and this offers great possibilities in the future to continue working on competences such as social and ethical responsibility, autonomous and team work, or decision-making and problem-solving through active methodologies.

However, the need to adapt a more traditional teaching-learning system in terms of training, spaces and resources is being limiting in order to obtain immediate positive final results.

The case study demonstrated that active methodologies in university higher education are beneficial for the whole educational community, achieving the motivation of an oftendisenchanted student body. But it also brought to light the need to adapt programmes to these new methodologies.

Finally, the results also suggest that could be desirable to design teaching case studies in the classroom where different groups of control and theoretical sample students are monitored.

This pilot experience is the beginning of new approaches in the teaching guides that favour bringing the academic closer to the reality of the environment in which university students will have to live in their professional future, enabling them to develop successfully in it. This raises 
Arcos-Alonso, A., Garcia-Alvarez, M \& Azpuru, A. G., (2022). Macroeconomics and active methodologies in higher education: A possible pairing and a possible binomial. Cypriot Journal of Educational Science. 17(1), 193-204

https://doi.org/10.18844/cjes.v17i1.6695

the possibility of renewing university programmes in order to implement active methodologies that are more in line with the needs of today's society, and which take into account the whole range of limitations mentioned above, also giving specific weight to the use of ICTs.

\section{References}

Arcos-Alonso, A. \& Alonso-Olea, M.J. (2020). Trabajando competencias transversales en estadística, mediante la economía social y solidaria. In Gonzalvez, J.E. (Ed.), Estudios sobre innovaciones educativas. Madrid, Spain: Ediciones Piramide.

Arcos-Alonso, A., \& Arcos Alonso, A. (2021). Problem-based learning and other active methodologies as support for distance teaching during the COVID-19 pandemic. Cypriot Journal of Educational Science. 16(1), 277-287 https://doi.org/10.18844/cjes.v16i1.5525.

Arcos-Alonso, A., Elías-Ortega A., \& Arcos Alonso, A. (2020). Intergenerational Service-Learning, Sustainability and University Social Responsibility: A Pilot Study. Cypriot Journal of Educational Science. 15(6), 1629-1641. https://doi.org/10.18844/cjes.v15i6.5322

Arcos-Alonso, A., Gezuraga M., Berasategi N. \& Ibarrondo, A. (2018). Fortaleciendo vínculos universidadsociedad con el aprendizaje servicio crítico y la economía social y solidaria. In Universidad otra. Otros sujetos, otros conocimientos, otras alianzas para una Universidad que transforma, 89-96.

Bilbao, Spain: Hegoa. Retrieved from https://bit.ly/2Uw4f8T

Boud, D. \& Feletti, G. (Eds.) (2013). The challenge of problem-based learning. London, UK: Routledge. Retrieved from https://doi.org/10.4324/9781315042039

Brown, M. \& Long, P. (2006). Trends in learning space design. Learning spaces, 9, 1-9. Retrieved from https://bit.ly/38HeRqx

Butler, A., Phillmann, K.B. \& Smart, L. (2001). Active learning within a lecture: assessing the impact of short, in-class writing exercises. Teaching of Psychology, 28(4), 257-259. doi:10.1207/S15328023TOP2804_04

Carazo, P.C.M. (2006). El método de estudio de caso: estrategia metodológica de la investigación científica. Pensamiento \& gestión, (20), 165-193.

Cárdenas, M.L. \& Rivera, J.F. (2004). La teoría de la complejidad y su influencia en la escuela. Revista de Teoria y Didactica de las Ciencias Sociales, (9), 131-141. Retrieved from https://bit.ly/39778Cp

Del Rio, A. \& Celorio, G. (2018). Emancipatory critical education. Diagnosis at the University of the Basque Country (UPV/EHU) (2011-2015). Bilbao, Spain: Hegoa. Retrieved from https://bit.ly/3cQ9kky

Eisenhardt, K.M. (1989). Building Theories from Case Study Research. Academy of Management Review, 14( 4): 532-550.

Forsythe, F.P.

- (2002). Problem-based learning. In Davies, P. (Ed.), The handbook for economics lecturers. The Economics Network. Retrieved from https://bit.ly/33bMKib

Freeman, S., Eddy, S.L., McDonough, M., Smith, M.K., Okoroafor, N., Jordt, H. \& Wenderoth, M.P. (2014). Active learning increases student performance in science, engineering, and mathematics. Proceedings of the National Academy of Sciences, 111(23), 8410-8415. doi:10.1073/pnas.1319030111

Garay-Argandona, R., Rodriguez-Vargas, M.C., \& Hernandez, R.M., Carranza-Esteban, R., Turpo, J.E. (2021). Research competences in university students in virtual learning environments. Cypriot Journal of Educational Science. 16(4), 1721-1736. https://doi.org/10.18844/cjes.v16i4.6031

Hernandez, S.M., Renart, M.A. \& Manzano, M.P. (2009). An empirical study of economists and the new graduate and postgraduate economics' degrees. Innovar, 19, 111-129. Retrieved from https://bit.ly/2UKROkC

Hmelo-Silver, C.E. (2004). Problem-based learning: what and how do students learn? Educational Psychology Review,16, 235-266. doi:10.1023/B:EDPR.0000034022.16470.f3 
Arcos-Alonso, A., Garcia-Alvarez, M \& Azpuru, A. G., (2022). Macroeconomics and active methodologies in higher education: A possible pairing and a possible binomial. Cypriot Journal of Educational Science. 17(1), 193-204

https://doi.org/10.18844/cjes.v17i1.6695

Jimenez, J.J., Lagos, G. \& Jareno, F. (2013). Problem-Based Learning as a tool to enhance transversal competences. Revista electrónica sobre la enseñanza de la Economía Publica, (13), 44-68. Retrieved from https://bit.ly/3aqTGL8

Kinsella, S. (2008). Teaching structuralist economics using problem-based learning and weblogs. The Economics Network. Retrieved from https://bit.ly/2vY1wNb

Klein, L. (2008). Using a problem-based learning exercise to motivate intermediate macroeconomics students to learn the IS-LM model. SSRN Electronic Journal. doi:10.2139/ssrn.1272719

Lopez, B., Benedito, J. \& Leon, M.J. (2016). The competence approach in university education and its impact on assessment. The perspective of a group of professional experts in Pedagogy. Formacion Universitaria, 9(4), 11-22. doi:10.4067/S0718-50062016000400003

Maxwell, N., Mergendoller, J. \& Bellisimo, Y. (2004) Developing a problem-based learning simulation: an economics unit on trade. Simulation and Gaming, 35(4), 488-498. doi:10.1177/1046878104264789

Mergendoller, J.R., Maxwell, N.L. \& Bellisimo, Y. (2006). The effectiveness of problem-based instruction: a comparative study of instructional methods and student characteristics. Interdisciplinary Journal of Problem-based Learning, 1(2), 49-69. doi:10.7771/1541-5015.1026

Miguez, G.C. \& Gil, M.D.G. (2012). Innovando la docencia superior en Economía: trabajo cooperativo y elaboracion participativa de contenidos. Revista de Docencia Universitaria, 10(2), 319-327. doi:10.4995/redu.2012.6110

Ortiz, E. (2019). Problem-based learning as a university teaching innovation and improvement experience. Perfiles Educativos, 41(164), 208-213. doi:10.22201/iisue.24486167e.2019.164.59223

Penalosa, E. (2019) Problem-based learning: review and practical proposals. In Espinosa, M., Garcia, A., Hernández, G., Moreno, T. (Eds),Didactics in action: different ways of teaching at university (pp.3350). México: Universidad Autónoma Metropolitana. Retrieved from https://bit.ly/2wSSJvV

Prieto, A., Barbarroja, J., Álvarez, S. \& Corell, A. (2021). Eficacia del modelo de aula invertida (flipped classroom) en la enseñanza universitaria: una síntesis de las mejores evidencias. Revista de Educación, 391, 149-177.

Rauber, I. (2011). Two steps forward, one step back. Logics of overcoming civilisation governed by capital. Bogota, Colombia: Ediciones Desde Abajo.

Salinas, J. (2004). Teaching innovation and the use of ICT in university teaching. Revista Universidad y Sociedad de Conocimiento, 1(1), Article 3. doi:10.7238/rusc.v1i1.228

Sarkar, S. (2012). The role of information and communication technology (ICT) in higher education for the 21st century. Science, 1(1), 30-41. Retrieved from https://bit.ly/2TX75mZ

Schmidt, H.G., Rotgans, J.I. \& Yew, E.H. (2011). The process of problem-based learning: what works and why. Medical Education, 45(8), 792-806. doi:10.1111/j.1365-2923.2011.04035.x

Stake, R.E. (1998). Investigación con estudio de casos. Ediciones Morata.

Wood, D.F. (2003). ABC of learning and teaching in medicine: problem-based learning. British Medical Journal, 326(7384), 328-330. doi:10.1136/bmj.326.7384.328 